IRINA RODIONOVA

TATIANA KOKUYTSEVA

Peoples' Friendship University of Russia, Moscow

\title{
Structural changes of world industry in postindustrial society and structural shifts in the world high-tech production allocation
}

\section{INTRODUCTION}

The modern world industry is varied due to its difficult and rather diversified structure. The branch structure of the industrial economy sector of different world countries depends on the set of factors: the level of social and economic development of states, the resource and industrial potential, the capacity of domestic market, the availability and the qualification degree of labour resources, the intensity and efficiency of the implementation of the achievements of scientific and technical progress in the industrial sphere, the degree of involvement of the country in the world economy, and the models of participation in the international labour division.

Processes of globalization and manufacture internationalization influence the changes of the economy structure as they influence the activity of large, medium and even small enterprises in different countries all over the world, which have turned into independent manufacturers mostly focused on the regional or even world market, instead of the state domestic market.

In the end of the 20th century and the beginning of the 21 st century, the rapid development of a service sector, the labour productivity growth in the industries and the strengthening of the international competition in the world market of goods have actually led to the reduction of not only the secondary sector, but also the share of directly manufacturing industry in the world gross national product. But, from the beginning of the 2000s, the share of the secondary sector of economy in the world gross national product and the manufacturing industry share again have begun to increase. It has occurred, first of all, due to the rapid development of the industry and the growth of employment in the secondary sector of economy and in the sphere of industrial services in China and some other developing countries.

\section{Changes In The Industrial STRUCTURE OF THE WORLD MANUFACTURING}

The ongoing changes in the structure of the industrial sector of developed economies by their nature differ from those which occur in developing countries. Also these changes 
differ by speed and nature due to regions' size. The implementation of new technologies and other scientific and technical progress achievements into the production process, the boost of efficiency and quality indicators of production in different countries were quick to reflect in changes of branch structure of manufacturing industry in the world. Many new industries were formed (bioindustry, manufacture of laser technology, modern medicine and microbiological drugs, etc.). Technological innovations gave birth to microelectronics. Therewith some well-defined stabilization and even a slight decline in production in ,traditional” industries of developed countries were observed. Highest growth rates were noticed in the production of means of communication (radio, television and communications equipment), computer and office equipment, or electrical equipment.

Among developing countries, the most intensive processes occurred in recent decades in China, Mexico, Brazil, India and ,new industrialization” Asian countries, where the same engineering sub-industries were highlighted. Yet, in the group of less developed countries the most significant growth rates were observed in industries traditional for these countries food and beverages, textiles, etc.

Data provided in the following table (Tab. 1) illustrate the obvious increase in share of communications (radio, television and communication equipment) in the structure of the world manufacturing (structure of MVA) and in selected country groups.

Tab 1. Structure of manufacturing value added (MVA) in selected country groups (in \%)*, 1995-2005

\begin{tabular}{|l|r|r|r|r|r|r|r|r|}
\hline \multirow{2}{*}{ ISIC(Rev.3) - Branch } & \multicolumn{2}{|c|}{$\begin{array}{l}\text { Industrialized } \\
\text { countries } \\
\text { without CIS }\end{array}$} & \multicolumn{2}{|l|}{ CIS countries } & \multicolumn{2}{|c|}{$\begin{array}{c}\text { Developing } \\
\text { countries }\end{array}$} & \multicolumn{2}{|c|}{ World } \\
\cline { 2 - 11 } & 1995 & 2006 & 1995 & 2006 & 1995 & 2006 & 1995 & 2006 \\
\hline Food and beverages & 11,0 & 8,2 & 17,5 & 18,2 & 15,6 & 11,9 & 12,2 & 9,4 \\
\hline Tobacco products & 0,7 & 0,4 & 0,5 & 0,8 & 2,9 & 3,0 & 1,2 & 1,2 \\
\hline Textiles & 2,3 & 1,1 & 3,0 & 2,3 & 6,2 & 4,6 & 3.2 & 2,1 \\
\hline Wearing apparel, fur & 2,6 & 0,8 & 1,8 & 1,4 & 3,2 & 2,6 & 2,7 & 1,4 \\
\hline $\begin{array}{l}\text { Leather, leather products and } \\
\text { footwear }\end{array}$ & 0,7 & 0,3 & 0,8 & 0,6 & 1,7 & 1,3 & 0,9 & 0,6 \\
\hline Wood products (excl. furniture) & 2,5 & 1,9 & 1,8 & 1,6 & 1,6 & 1,1 & 2,3 & 1,6 \\
\hline Paper and paper products & 3,7 & 2,6 & 2,7 & 3,1 & 2,4 & 2,2 & 3,4 & 2,5 \\
\hline Printing and publishing & 6,0 & 4,2 & 1,0 & 1,6 & 2,2 & 1,7 & 5,1 & 3,4 \\
\hline $\begin{array}{l}\text { Coke,refined petroleum products, } \\
\text { nuclear fuel }\end{array}$ & 3,1 & 2,3 & 5,4 & 4,6 & 7,5 & 5,9 & 4,2 & 3,4 \\
\hline Chemicals and chemical products & 10,0 & 8,9 & 8,3 & 8,1 & 9,8 & 9,7 & 10,0 & 9,1 \\
\hline Rubber and plastics products & 3,2 & 2,6 & 1,7 & 2,2 & 3,6 & 3,7 & 3,3 & 2,9 \\
\hline Non-metallic mineral products & 4,0 & 2,8 & 7,8 & 6,7 & 5,7 & 4,1 & 4,5 & 3,2 \\
\hline
\end{tabular}

${ }^{1}$ It is necessary to notice that the analyzed data (UNIDO INDSTAT4 2009. Industrial Statistics Database at the 4-digit Level of ISIC - Revision 2 and 3) has a considerable disadvantages. The data of the branch structure of industry of the countries and world regions is not absolutely exact. There are the following notes: For selected years total manufacturing excludes: ISIC 32 (Radio, television and communication equipment) - Russia; and also on ISIC 16 (Tobacco products) and ISIC 30 (Office, accounting and computing machinery) - Japan etc. But thus, even in the absence of the data of a branch the sum of relative density of all branches of a manufacturing industry, nevertheless, remained equal to $100 \%$ (i.e. the data of absent branches was simply replaced with zero indicators). 


\begin{tabular}{|l|r|r|r|r|r|r|r|c|}
\hline Basic metals & 5,2 & 3,9 & 16,0 & 15,8 & 6,7 & 7,5 & 5,7 & 5,1 \\
\hline Fabricated metal products & 7,2 & 5,4 & 4,3 & 5,0 & 4,4 & 3,6 & 6,5 & 4,9 \\
\hline Machinery and equipment n.e.c. & 9,4 & 7,5 & 10,8 & 8,7 & 5,9 & 5,6 & 8,6 & 7,0 \\
\hline $\begin{array}{l}\text { Office, accounting and comput- } \\
\text { ing machinery }\end{array}$ & 1,8 & 3,7 & 0,2 & 0,3 & 1,2 & 1,0 & 1,7 & 2,9 \\
\hline $\begin{array}{l}\text { Electrical machinery and ap- } \\
\text { paratus }\end{array}$ & 4,1 & 3,8 & 2,8 & 3,3 & 3,9 & 6,9 & 4,1 & 4,7 \\
\hline $\begin{array}{l}\text { Radio,television and communica- } \\
\text { tion equipment }\end{array}$ & 5,6 & 25,0 & 1,5 & 1,6 & 4,6 & 11,0 & 5,3 & 20,6 \\
\hline $\begin{array}{l}\text { Medical, precision and optical } \\
\text { instruments }\end{array}$ & 2,5 & 2,6 & 1,5 & 3,7 & 0,9 & 0,8 & 2,1 & 2,1 \\
\hline $\begin{array}{l}\text { Motor vehicles, trailers, semi- } \\
\text { trailers }\end{array}$ & 7,6 & 7,2 & 4,0 & 4,1 & 4,1 & 3,9 & 6,7 & 6,2 \\
\hline Other transport equipment & 2,5 & 2,3 & 4,2 & 3,8 & 3,0 & 5,5 & 2,6 & 3,2 \\
\hline Furniture; manufacturing n.e.c. & 4,2 & 2,8 & 2,5 & 2,5 & 3,0 & 2,4 & 3,8 & 2,6 \\
\hline
\end{tabular}

* Percentage shares of individual branches in total MVA at constant 2000 prices

Source: UNIDO INDSTAT4 2009. Industrial Statistics Database at the 4-digit Level of ISIC (Revision 2 and 3), 2009, accessed online: http://www.unido.org/index.php?id=4879)

Changes in the industrial structure of developed countries, which are entering the new post industrial stage, in essence, determined the structural changes in the global industry.

Specific processes occurred in the same period in the post-Soviet space, particularly in the CIS countries, which restructured the entire economic complex by passage „from plan to market”. During the period of economic recession of 1990-1998, in industrial output Russia declined by $60 \%$ (and reached its lowest point in August $1998-37 \%$ of the 1990 levels), but over the years (almost 10 years until 2008) Russia saw the rise and development and with this production volume of its industry it reached (on average) just over $66 \%$ of the level of January 1990. In other words, even taking into account the recovery and reconstruction of the whole country's industry, Russia did not mature, when the global economic crisis descended. It should be noted that the rate of growth of manufacturing industries (excluding iron and steel) in the 2000s significantly lagged behind the growth of the economy as a whole, and their share in industrial production declined over all these years. In the first place, in the structure of manufacturing industry in Russia there is metallurgical production and manufacture of fabricated metal products (around 22\% in 2008), and only on the second place - production engineering - about $22 \%$ (including the share of electrical, electronic and optical equipment, accounting for only about 6\%) (Russia in figures. 2009). Very similar was the situation in other CIS countries in 1990-2000.

As for the developing countries, the structure of their industry also changed. But especially noticeable changes have occurred due to changes in only a few of them, such as Brazil, Mexico, the Asian NIC of the „first” and „second wave” (Korea, Singapore, Malaysia, Thailand and others). At the same time, in the industrial structure of these states there occurred a shift toward development of knowledge-intensive branches. The proportion of developing countries in manufacturing in the World over the past decade has increased significantly. Thus China, Asian NIC and other states (with priority to manufacturing industries) significantly strengthened their positions in the global economy. 
To sum it all up, we are noting the following. In most developed countries, changes in the structure of industrial production (before the current financial and economic crisis in the global economy since 2008) were a process of gradual restructuring and adjustment of the economy through the introduction of scientific and technological progress in the transition to post-industrial stage of development due to increasing income of population. Priority is given, in the first place, to the most high-tech industries and branches. In the CIS countries (and many other countries with the same "transition economies") ever since the early 1990 s, changes in the industrial structure of industry have identified the transformation of the economic mechanism and the restructuring of the economy, and now, because of that, they reflect general economic problems of this type of countries. For groups of less developed countries, structural changes in the industrial sector of the economy were expressed in the process of changing the organization and methods of production in large-scale changes in productivity and in the industrial structure due to the deeper involvement of these countries in international division of labour. The multinational companies also have strong influence on the placement of production facilities on their territory, which strongly came through, for example, in changing of industrial structure in Asian NIC countries with their export-oriented economies. And in the less developed countries of the World, there were no significant changes in the industrial structure.

\section{LEADERS OF THE WORLD MANUFACTURING}

Most of the technological capacity and industrial production (in value terms) remains concentrated in the developed countries $(70 \%)$. At the same time, the share in world manufacturing value added (MVA) increased very significantly in China, which took the third place in the world ranking, primarily due to the rapid growth of gross production (Tab. 2).

Tab. 2. Top-15 of the world manufacturing (world MVA), 2006 (at constant 2000 prices)

\begin{tabular}{|l|c|c|c|c|}
\hline Country & $\begin{array}{c}\text { Country's share } \\
\text { in world MVA, } \\
\%\end{array}$ & $\begin{array}{c}\text { MVA as per- } \\
\text { centage of GDP }\end{array}$ & $\begin{array}{c}\text { Country's share in } \\
\text { world manufactured } \\
\text { exports, } \%\end{array}$ & $\begin{array}{c}\text { MVA per capita, at } \\
\text { constant 2000 US\$ } \\
\text { prices }\end{array}$ \\
\hline 1. USA & 25,1 & 15,0 & 12,0 & 5630 \\
\hline 2. Japan & 15,8 & 21,0 & 7,9 & 8383 \\
\hline 3. China & 10,6 & 34,5 & 12,4 & 543 \\
\hline 4. Germany & 6,3 & 21,3 & 13,2 & 5215 \\
\hline 5. Great Britain & 3,3 & 13,5 & 5,0 & 3757 \\
\hline 6. France & 3,0 & 14,1 & 5,7 & 3378 \\
\hline 7. Italy & 2,95 & 17,4 & 5,1 & 3509 \\
\hline $\begin{array}{l}\text { 8. The Republic of } \\
\text { Korea }\end{array}$ & 2,9 & 29,8 & 4,2 & 4129 \\
\hline 9. Brasilia & 2,0 & 19,8 & 1,4 & 744 \\
\hline 10. Canada & 2,0 & 16,2 & 3,6 & 4198 \\
\hline 11. Mexico & 1,7 & 19,2 & 2,7 & 524 \\
\hline
\end{tabular}




\begin{tabular}{|l|l|l|l|r|}
\hline 12. Spain & 1,6 & 15,6 & 2,4 & 2660 \\
\hline 13. Taiwan & 1,5 & 25,8 & 2,8 & 4420 \\
\hline 14. India & 1,5 & 14,4 & 0,7 & 92 \\
\hline 15. Russia & 1,1 & 19,9 & 1,6 & 528 \\
\hline
\end{tabular}

Source: UNIDO INDSTAT4 2009. Industrial Statistics Database at the 4-digit Level of ISIC (Revision 2 and 3), 2009, accessed online: http://www.unido.org/index.php?id=4879).

Informatization, according to the leaders of China, is an important strategic resource element, determining the prospects of the entire economic and social modernization. It is worth emphasizing the fact that the position of China in the world economic system, that had previously been provided mostly by low production costs in the supply of products to foreign markets shallow redistribution (textiles, sportswear, toys), now occurs due to increased export earnings from trade in high-tech products . The current situation in Russia, by contrast, is characterized by a lag in the development of the high-tech sector of economy. Our country is a consumer of the simplest and most popular technologies. In the present rating our country occupies the 15 th place, and it accounts for only about $1 \%$ of world production of manufacturing industries.

The data presented in the above table (Tab. 2) illustrate the differing performance of the leading countries on such indicators as MVA as percentage of GDP, MVA per capita at constant 2000 US\$ prices, country's share in world manufactured exports (\%). The analysis shows that yet again Russia has no advantages (we have a ten-fold gap from the leaders). For example, in Japan's index of MVA per capita, data for 2006 correspond to 8383 dollars (at constant 2000 US\$ prices), Switzerland - 7054 dollars, in Singapore - 6853 dollars, in the U.S. -5630 dollars, to compare this figure (US\$): Brazil - 743, China - 543, Russia -528, Mexico - 524, Indonesia -275, India - 92, Nigeria - 19, Ethiopia - 6 (UNIDO INDSTAT4, 2009).

It is also worthwhile noting that the top five leaders of the world industry accounts for approximately $60 \%$ of world production of manufactures (and the share of the first 15 countries $-80 \%$ ), indicating a high level of concentration of production capacity in a group of leading countries. In this group of leading countries, apart from China, are already South Korea, Brazil, Mexico and India. They are followed by Argentina, Indonesia and Thailand, which have overtaken Sweden, the Netherlands, Australia, Switzerland and many other developed countries. In countries that create and widely use in practice innovative technology and their diffusion in the branches of parent TNCs worldwide, per unit of capital in the manufacturing industry is many times as large an output in value terms as in capital-intensive extractive industries and manufacture of the lowest redistributions.

In other words, the most impressive results were achieved by the countries that have managed to put at the service of national economy the benefits of the globalization of world markets for high-tech products, where winning a strong position gives a significant profit as compared to domestic production costs of high technology products and services (the socalled technological rents).

At the same time, in modern Russia the simple use of the intellectual, technical, scientific and technological capabilities of previous years without its building and development dooms the industry and economy to the inevitable and growing backlog. It is worth remembering that this is happening against a background of accelerating the practical application of scientific knowledge embodied in the innovation, and strengthening scientific and technological capabilities of many countries, not only the economically highly developed ones. 


\section{THE ROLE OF URBAN AGGLOMERATIONS IN THE PRODUCTION}

OF INDUSTRIAL PRODUCTS

Recently, the processes of globalization, transnationalization of production, and increase in the value of services gave a direct impact on changes in the structures, functions of cities and their role in public life. In the scientific literature a popular term is ,global cities”, which are regarded as postindustrial centres, fully integrated into the global economy. Scholars such as S. Sassen, P. Taylor, P. Marcuse, H. Trift, G. Wolf, J. Fridman, N.S luka and others research problems and trends of development of global cities. Urbanization and industrialization have always marched in lockstep. No country has reached the average level of income without industrialization and urbanization. No country has reached a high level of income without prosperous cities. Production is concentrated in large cities, the most developed areas of individual countries and rich countries. Half of the total world production is concentrated in one and a half per cent of the world (World Development Report 2009).

The global cities today are not only the world's financial centres, but also important in the global manufacturing, major transportation and communication centres. N. Sluka stresses that the term ,de-industrialization”, which characterizes the post-industrial economy and is often used when describing the trends of global cities, is in some way misleading (Sluka, 2007). The fact is that the share of mass production in big cities rapidly decreases. However, given the increasing role of information, knowledge and innovation, high-tech production is actively developing. Indigenous change of technology, production organization and nature of the products lead to increased specialization of the industrial complex in the global cities. Here, as underlines A. Gorkin, in the most concentrated form attributive production of post-industrial and industrial complex is developed, that means those industries whose products are made in terms of „compression” of space and time, and which contribute to meeting the growing needs of society and every person in the media, extending human life, preservation of health and a healthy lifestyle, environmental protection, conservation of biota (Gorkin, 2004. P. 386).

Analyzing the economic activity in major industrial and urban agglomerations world price value added in manufacturing, A. Gorkin comes to a very important conclusion. Comparing the figures for large-RBM corporate urban agglomerations, data on production volumes in selected countries and regions of the world, he notes that the industrial production of the Greater Tokyo (Japan) is about 9/10 of manufacturing in Africa. Industrial capacity in Los Angeles (USA) is comparable with that in a country with 200 million people - in Indonesia. For industrial production, the capital of the Republic of Korea, Seoul, is ahead of Turkey, Shanghai (China) - ahead of Belgium, and Boston (USA) - of Portugal. In other words, it is emphasized that the geography of manufacturing of industry of the world is the geography of cities and towns (Gorkin, 2008. P.31).

N. Sluka comes to similar conclusions, describing the economic power of the elite global cities (New York, London, Paris and Tokyo), and noting that the total of these 4 metropolitan areas accounts for only less than $2 \%$ of the urban population of the world, but at the same time - about $10 \%$ of world GDP, over $10 \%$ cargo and passenger air transport, as well as the volume of international business travel. Moreover, in these cities is located more than $25 \%$ of the headquarters of TNCs from among the 500 largest nonfinancial companies in the world, according to the Global-500 list, and nearly $50 \%$ of global companies of the media 
industry. At the same time, these cities are the global epicentre of data traffic and financial exchange, and the largest hubs of scientific and technological innovation. And he further emphasizes that in fact the leading global centres (the largest urban agglomerations in the world, global cities) act as guiding and controlling centres of the world economy (Sluka, Tkachenko, 2009. P. 240-241). It is also noted that the structure of global cities in the industry now plays a primary role of the «innovative» block sector of industry, which is closely related to the scope of research and development and focuses on international markets. It is represented, first of all, as "the upper floors" of the production chain: the production of precision engineering products, electronic industry, as well as fine chemicals. And the efficient development of this block of industries is a pledge of economic growth and prosperity not only for the major cities, but also the country as a whole. As if confirming this thesis, in our study, comparing the volumes of production-intensive sectors at the level of world dynamics since 1985, special attention was paid to trends in high-tech production in the countries of EU, given the high level of urbanization and industrialization in the European region, as well as to the fact that the Ruhr, London and Paris metropolitan area are among the 10 biggest industrial-urban agglomerations of manufacturing value (along with Tokyo, Los Angeles, New-York, Seoul, Chicago and others).

\section{CURRENT TRENDS IN THE GLOBAL INDUSTRY}

Knowledge-intensive industries and high technology now plays a major role in the development of the economy and social sphere. They materialize the bulk of research and development. They determine the demand for scientific research (and, hence, contribute to the further development of science) and create a base material and offer real innovation and information for all sectors of the economy. The importance of innovation development course, was understood long ago in the European Union, however, and in this integration, there are significant differences between the member countries as for the levels of high-tech industry. Therefore, the question of logical trends in hi-tech industry in the EU-27 is of great interest for the study and is very relevant, especially in the context of the current financial crisis.

In the recent decades, the global industry (in addition to changes in industrial structure towards increasing share of high-technology industries) affects directly the structure of high-tech or knowledge-intensive industries. It is known that the classification of industry or production of a number of high-tech goods adopted in the scientific literature is quite conditional. This group of industries recorded more than a certain fixed level of relative cost of $R \& D$ in the production of products. This is the proper measure of research intensity, which is determined by expenditure on R\&D (including per unit gross value of production).

We analyzed data on high-tech production ("high-technology manufacturing industries"), including information on the following five industries: aerospace, pharmaceuticals, office and computing machinery, communication equipment, medical, precision, and optical instruments, allocated in terms of Research and Development intensity. Analysis of data showed that in the period from 1980-2005 the structure of production of high technology products has changed in the direction of increasing the production of means of communication (increasing the share of 23,6 to $45,3 \%$ ). In the second place in the structure now is the pharmaceutical industry, then - the production of scientific equipment (reducing the 
proportion of 26 to $14 \%$ ) and production of computer technology. These are changes in the industrial structure of industry of developed countries that joined the post-industrial stage of development, and these changes were crucial for structural shifts in the global economy.

The largest manufacturers of all types of high-tech products are still the USA, EU and Japan, calculations showed that, overall, the production of high technology products in the world (a total of five sectors highlighted above) in 2005, were leading: United States (34,5\% of the world production at constant 2000 prices), Japan (around 17\%), China (16\%), Germany (5\%), South Korea (4\%), United Kingdom (3\%), France (3\%). The total share of EU countries amounted to about $1 / 5$ of world production ${ }^{2}$.

The share of high-technology products increased both in the structure of the manufacturing industry of the world, and in the industrial sector of the economy of individual countries including developing countries - particularly China and the Asian NIC, and some countries in Latin America. These changes indicate an increase in industrial structure and global structure of the industry share of mechanical engineering, chemistry and other industries that use the latest achievements of scientific and technical progress.

Since 1985, the structure of the manufacturing world has also changed as a whole. OECD identifies four groups of manufacturing industries in terms of applied technologies: high technology manufacturing industries, medium-high-technology industries, medium-low technology industries and low-technology industries. High-technology production is production of aircraft and spacecraft, pharmaceuticals, office, accounting and computing machinery, radio, TV and communications equipment, medical, precision and optical instruments. Mediumhigh-technology industries include: electrical machinery and apparatus, motor vehicles, trailers, semi-trailers, chemicals (excluding pharmaceuticals), railroad equipment and transport equipment, machinery and equipment n.e.c. Medium-low-technology production includes: building and repairing of ships and boats, rubber and plastics products, coke, refined petroleum products, nuclear fuel, other non-metallic mineral products, basic metals and fabricated metal products. Low-tech production includes: manufacturing n.e.c., recycling, wood, pulp, paper and paper production, printing and publishing, food products and beverages, tobacco products, textiles, textile products, leather and footwear, etc.

In the period from 1985 to 2005 , this proportion of high-technology industries increased from $11,7 \%$ to nearly $20 \%$ by reducing the proportion of low-technology (from $37 \%$ to $31 \%$ ) and medium high-technology production (from $29 \%$ to $27 \%$ ). However, the share of knowledge-based production, both in exports and in imports of manufactured goods has grown even more rapidly than in manufacturing. World exports of industrial production of hightechnology products increased from $12 \%$ to almost $30 \%$, with declining share of output of medium-and low-technology production (Tab. 3).

As a result of the study, significant changes were noted in the specialization of the world in MRI, and in the alignment of forces in world production and trade in industrial products. For example, in 1985, leaders in exports of manufacturing industry were mainly developed countries, namely: the United States, Japan, EU - Germany, Britain, France (they dominated the export of products of different levels of adaptability, the only change in their rank was relative to each other). And now the group leaders, except China, are also in India and the Asian NIC. At the same time, China entered the top five leaders in manufacturing exports of all articles (the export of low-, medium-and high-technology products). In other

2 Calculated on the database: Science and Engineering Indicators. 2008. (Appendix tables 6). Two volumes. National Science Foundation. USA. VA: Arlington, accessed online: http://www.nsf.gov. 
words, the development of high technology changed the structure of the world market, which reflected the priorities of science and technology policy in different countries.

Tab. 3. Changes in the structure of manufactured exports, $\%$

\begin{tabular}{|l|l|l|l|}
\hline & 1985 г. & 1990 r. & 2005 г. \\
\hline Export of manufacturing industry, including: & 100,0 & 100,0 & 100,0 \\
\hline High-technology production & 12,2 & 14,6 & 28,9 \\
\hline Medium -high-technology production & 41,6 & 40,4 & 36,2 \\
\hline Medium -low- technology production & 18,8 & 16,6 & 13,0 \\
\hline Low-technology production & 27,4 & 28,4 & 21,9 \\
\hline
\end{tabular}

Calculated on the database: Science and Engineering Indicators. 2008. (Appendix tables 6). Two volumes. National Science Foundation. USA. VA: Arlington, accessed online: http://www.nsf.gov.

\section{Place of EU member states in the WORLD ECONOMY} AND MANUFACTURED TRADE

Analyzing the data to produce manufactured goods of different levels of adaptability (from low - and medium - to high-technology), we also see that many EU countries in 1985 and 2005 were, and of course are now, among the world leaders, and the largest of them are among the first five states of the world, accounting for the total of about $2 / 3$ release of lowtech products and up to $3 / 4$ of world production of high-technology products (Tab. 4).

Tab. 4. Country's share of the world manufacturing industry based on technology, 1985 and 2005 (at constant 2000 prices), \%

\begin{tabular}{|c|c|c|c|c|c|c|c|}
\hline \multicolumn{2}{|c|}{ High-technology indusries } & \multicolumn{2}{|c|}{$\begin{array}{c}\text { Medium - high-techno- } \\
\text { logy indusries }\end{array}$} & \multicolumn{2}{|c|}{$\begin{array}{c}\text { Medium - low- } \\
\text {-technology indusries }\end{array}$} & \multicolumn{2}{|c|}{$\begin{array}{l}\text { Low-technology } \\
\text { indusries }\end{array}$} \\
\hline Countries & Share & Countries & Share & Countries & Share & Countries & Share \\
\hline \multicolumn{8}{|c|}{ Top-5 of world MVA, 1985} \\
\hline USA & 33,2 & USA & 28,3 & USA & 24,8 & USA & 28,8 \\
\hline Japan & 25,3 & Japan & 19,3 & Japan & 17,7 & Japan & 18,9 \\
\hline Germany & 7,1 & Germany & 13,2 & Germany & 8,5 & Germany & 5,8 \\
\hline UK & 4,9 & UK & 5,9 & France & 6,1 & Italy & 4,8 \\
\hline Italy & 3,6 & Italy & 3,9 & Italy & 5,1 & UK & 4,6 \\
\hline EU (total) & 25,4 & $\mathrm{EU}$ (total) & 32,8 & EU (total) & 33,8 & EU (total) & 28,7 \\
\hline \multicolumn{8}{|c|}{ Top-5 of world MVA, 2005} \\
\hline USA & 34,5 & USA & 22,9 & USA & 22,0 & USA & 30,3 \\
\hline Japan & 16,2 & Japan & 20,7 & Japan & 15,1 & Japan & 13,9 \\
\hline
\end{tabular}




\begin{tabular}{|l|l|l|l|l|l|l|l|}
\hline China & 16,1 & Germany & 11,1 & China & 10,6 & China & 9,0 \\
\hline Germany & 4,8 & China & 7,8 & Germany & 6,5 & Germany & 4,6 \\
\hline Korea (South) & 3,6 & France & 3,3 & France & 3,9 & UK & 4,1 \\
\hline EU (total) & 18,4 & EU (total) & 28,2 & EU (total) & 25,2 & EU (total) & 30,3 \\
\hline
\end{tabular}

Calculated on the database: Science and Engineering Indicators. 2008. (Appendix tables 6). Two volumes. National Science Foundation. USA. VA: Arlington, accessed online: http://www.nsf.gov.

Tab. 5. Country's share in world manufactured exports, 1985 and 2005 (at constant 2000 prices), $\%$

\begin{tabular}{|c|c|c|c|c|c|c|c|}
\hline \multicolumn{2}{|c|}{ High-technology indusries } & \multicolumn{2}{|c|}{$\begin{array}{c}\text { Medium - high- } \\
\text {-technology indusries }\end{array}$} & \multicolumn{2}{|c|}{$\begin{array}{c}\text { Medium - low- } \\
\text {-technology } \\
\text { indusries }\end{array}$} & \multicolumn{2}{|c|}{$\begin{array}{l}\text { Low-technology indus- } \\
\text { ries }\end{array}$} \\
\hline Countries & Share & Countries & Share & Countries & Share & Countries & Share \\
\hline \multicolumn{8}{|c|}{ Top-5 of manufactured exports and share of EU, 1985} \\
\hline USA & 23,2 & Germany & 19,3 & China & 11,5 & USA & 10,6 \\
\hline Japan & 21,0 & Japan & 16,8 & Germany & 11,4 & Germany & 8,7 \\
\hline Germany & 11,5 & USA & 14,8 & USA & 7,5 & Italy & 8,0 \\
\hline UK & 7,9 & France & 6,3 & France & 6,1 & China & 6,4 \\
\hline France & 5,2 & UK & 5,9 & Italy & 5,6 & France & 5,8 \\
\hline $\begin{array}{l}\text { EU (without } \\
\text { intra-regional } \\
\text { trade) }\end{array}$ & 18,9 & $\begin{array}{l}\text { EU (without } \\
\text { intra-regional } \\
\text { trade) }\end{array}$ & 24,0 & $\begin{array}{l}\text { EU (without } \\
\text { intra-region- } \\
\text { al trade) }\end{array}$ & 19,7 & $\begin{array}{l}\text { EU (without } \\
\text { intra-regional } \\
\text { trade) }\end{array}$ & 19,6 \\
\hline EU (total) & 27,3 & EU (total) & 49,6 & EU (total) & 46,4 & EU (total) & 45,0 \\
\hline \multicolumn{8}{|c|}{ Top-5 of manufactured exports and share of EU, 2005} \\
\hline China & 19,5 & Germany & 14,2 & India & 10,7 & China & 16,1 \\
\hline USA & 11,6 & Japan & 13,1 & Germany & 9,7 & USA & 8,4 \\
\hline Japan & 9,1 & USA & 11,1 & USA & 6,6 & Germany & 7,6 \\
\hline Germany & 6,9 & China & 8,4 & China & 6,3 & Italy & 5,2 \\
\hline Taiwan & 6,5 & France & 5,7 & Indonesia & 4,9 & France & 4,4 \\
\hline $\begin{array}{l}\text { EU (without } \\
\text { intra-regional } \\
\text { trade) } \\
\end{array}$ & 11,4 & $\begin{array}{l}\text { EU (without } \\
\text { intra-regional } \\
\text { trade) } \\
\end{array}$ & 15,6 & $\begin{array}{l}\text { EU (without } \\
\text { intra-regio- } \\
\text { nal trade) } \\
\end{array}$ & 12,4 & $\begin{array}{l}\text { EU (without } \\
\text { intra-regional } \\
\text { trade) } \\
\end{array}$ & 12,5 \\
\hline EU (total) & 28,2 & EU (total) & 43,7 & EU (total) & 40,9 & EU (total) & 40,0 \\
\hline
\end{tabular}

Calculated on the database: Science and Engineering Indicators. 2008. (Appendix tables 6). Two volumes. National Science Foundation. USA. VA: Arlington, accessed online: http://www.nsf.gov.

An interesting fact is that the total share of the EU (even without taking into account intra-commerce within the EU) in export of all types of manufacturing is bigger than the U.S. share of world exports, and while taking into account the trade within the EU - far more 
than this. This certainly describes the strengthening of the position of the European Union in international trade in finished products, but also points to the emergence of a new competitor - China, whose share in the production and manufacturing exports has been steadily increasing. Thus, in the period from 1985 to 2005, Chinese exports of high-technology manufacturing industries has increased 76 times - from 5,8 up to 440 billion dollars (over the same period in the USA this figure has increased about 5 times - from 52 to 250 billion dollars, in Japan - in 4,5 times from 47,5 to 205 billion dollars). On exports and imports of high-tech products, China has reached the 1-st place (exports: about $20 \%$ of world total in 2005 against $2,5 \%$ in 1985 , import $-17 \%$ versus $6 \%$ ), ahead of the USA $(12 \%$ in 2005 against $23 \%$ in 1985), Japan (9\% versus $21 \%$ ) and Germany (7\% versus $11,5 \%) .{ }^{3}$ At the same time, right behind the group of leaders are Taiwan, Republic of Korea, Singapore, Malaysia, and they are often ahead of many European countries.

Note that different trends were revealed in the development of high-tech production in the EU. If the average production volume of high technology products (in value terms at constant 2000 prices) for the EU increased about two-fold, and roughly at the same rate increased the production of high-tech products in most EU countries, where the value for this type of product grew more rapidly. In general, there are three groups of EU countries: where the issue of high-tech commodities in 20 years remained almost at the same level (Spain, Italy, Netherlands, Bulgaria), where production volumes have grown by low rates (the majority of EU countries, including Eastern European countries), and countries with the highest rates of development of new technologies. For example, in Ireland, production of high-tech products increased 12 times, in Finland - 9, and the Czech Republic - 8 times, in Hungary only in 2000 s - 4-fold. These countries have increased their share in world production of manufactures, and high-tech products in particular, although the leaders among the EU member states are still Germany, France, Britain, and Italy, while the fifth position is already Ireland, and the 6th - Finland, ahead of Belgium and Sweden. What should be noted is the overall reduction in the proportion of the EU from $25 \%$ to $18 \%$ in production of high technology, primarily by increasing the share of Asia (from 29 to $41 \%$ in 2005), with stable high proportion of the USA (1/3 of world production).

\section{CONCLUSION}

In conclusion, we would like to emphasize the following thought. Information technologies play a gradually greater role in the world economy; moreover, the so-called ,digital rupture", that is a backlog of the poorest countries behind the rich ones by volumes and quality of use of these technologies, is gradually reduced. Those countries which have managed to get advantages of globalisation of the world markets of hi-tech production have achieved the most considerable results.

The general share of hi-tech production in the export of civil industrial goods of Russia amounts to about $2 \%$, and it has been constantly decreasing for the last years. The countries of East and South East Asia in which the share of the hi-tech goods in the export structure is ten times higher and, besides, promptly grows, make a serious competition not only to

\footnotetext{
${ }^{3}$ Calculated by the authors on the database: Science and Engineering Indicators. 2008. (Appendix tables 6). Two volumes. National Science Foundation. USA. VA: Arlington, accessed online: http:/www.nsf.gov.
} 
Russia, but also to many large world exporters, as a result replacing their hi-tech export with low-tech products, mainly, raw products.

In the conditions of open economy, the Russian goods, non-competitive on foreign markets, quickly lose competitiveness on internal ones, being superseded by import. In these conditions the whole branches start to lack financial resources, which sooner or later leads to their irreversible technological degradation or total disappearance.

A positive tendency is that for years of reforms Russia has been in search for sale markets. Comparison of Russian and world indexes of export specialisation confirms it. For our country, hi-tech chemical technologies, nanomaterials, civil aircraft, nuclear reactors working on fast neutrons, cheap military technologies, and also aerospace engineering can become perspective.

Considering the weakness of the industrial potential of the Russian Federation, the strategy based on the trade of technologies can become productive. However, the activity of the Russian applicants on the foreign markets of technologies is still insignificant.

If radical measures to innovative economy are not taken on transition, Russia and other CIS countries may remain at the level of the developing states (and not such as China or the newly industrialized economies of South East Asia), basically exporting raw and energy resources.

It is necessary to create the innovative economy of the Commonwealth of Independent States by common efforts, through modernization of industrial and technological base, and labour productivity growth.

In the conditions of the modern crisis, the necessity of transition to the innovative model on the basis of the interstate cooperation has rapidly appeared, which synergetic effect will help the CIS countries to pass to a higher technological path. One of the priorities now is creation of the single market of the CIS countries. From the 1st of January, 2010, the Customs union will start to operate. By 2015 the total integration effect from the creation of the Customs union of Russia, Kazakhstan and Belarus will make (under the forecast of experts) about 400 bln. dollars. Calculations are made by the scientists of the Institute of Economic Forecasting of the Russian Academy of Sciences. Scientists confirm that the elimination of traffic barriers in mutual trade of the three countries will provide, in total, the growth of gross national product of an integration by $15-20 \%$ by 2015 .

In other words, the use of intellectual, scientific and technical and technological potential of the last years, without its escalating and development in modern Russia and other CIS countries, dooms the industry and economy of our countries to an inevitable and accruing backlog. Thus, it is worth remembering that it occurs as the process of practical use of the scientific knowledge embodied in innovations accelerates, scientific and technical and technological possibilities of variety of the countries, not only the advanced ones.

\section{References}

Gorkin A., 2008, The space organization of world manufacturing industry at the beginning of the XXI century: methodology and methodics of analysis /Bulletin of Peoples' Friendship University of Russia. Series Economics, № 1. P. 23-31.

Gorkin A., 2004, The postindustrial industrial complex (problems and features of macro-geography) / Geography, society, environment. T. 5. The geography of socio-economic development. Moscow. P. 384-399. 
Russia in figures, 2009, Brief statistical review. Short stat. Book. Federal Service of State Statistics (Rosstat): Mockow.

Science and Engineering Indicators, 2008, (Appendix tables 6). Two volumes. National Science Foundation. USA. VA: Arlington, accessed online: http://www.nsf.gov.

Sluka N., 2007, The global city: theory and reality/Demoscop Weekly. Moscow.

Sluka N., Tkachenko T., 2009. The global city: specialities of industrial development/Changes of spatial organisation of world industry: XX в. - XXI в. /Edited prof. I. Rodionova. Econ-Info: Moscow.

UNIDO INDSTAT 2009. Industrial Statistics Database at the 4-digit Level of ISIC (Revision 2 and 3), 2009, accessed online: http://www.unido.org/index.php?id=4879).

World Development Report. 2009. Reshaping Economic Geography. World Bank. Washington. USA, accessed online: http://www.worldbank.org/publications.

\section{Structural changes of world industry in post-industrial society and struc- tural shifts in the world high-tech production allocation}

This research is dedicated to the characteristic of structural spatial shifts of the world manufacturing industry. These trends have conduced to the restructuring of the world economy and main shifts in the manufacturing locations both at regional and global levels. On the one hand, countries have got a great chance to develop and to become active players in the world economy. On the other hand, those that fell behind the scientific and technological revolution, which started in the second part of the 20th century, and did not do their best to create new high technologies (or just did not have such opportunities because of a low level of development, illiteracy or people poorness) turned out to be behind global leading economies.

Structural shifts both in manufacturing location and in industrial composition occur very quickly in the recent decades. There have been shifts in the HT-industry composition. The shift to developing Asian countries is fixed and there are some reasons for that. That is why the theme chosen for this paper is not very researched and rather burning. Moreover, it has practical importance for Russia, which in the current financial crisis once again has faced a choice to define the strategy of its further development.

Prof. dr Irina Rodionova

Peoples' Friendship University of Russia, Moscow

Department of Regional Economy \& Geography

Faculty of Economics Peoples'

e-mail: iarodionova@mail.ru

Tatiana Kokuytseva

Peoples' Friendship University of Russia, Moscow

Faculty of Economics

e-mail: tk-snejinka@mail.ru 